\title{
Artificial wetland planted with Limonium Perezzi, for the treatment of wastewater from tanning
}

\author{
Humedal artificial plantado con Limonium Perezzi, para el tratamiento de aguas residuales \\ provenientes del curtido
}

\author{
María Fernanda Castillo-Castañeda (i] ${ }^{1 *}$ Rafael Nikolay Agudelo-Valencia \\ ${ }^{1}$ Facultad de Ingeniería, Universidad Libre. Carrera 70 \# 53-40. C.P. 111071 . Bogotá, Colombia.
}

\section{CITE THIS ARTICLE AS:}

M. F. Castillo and R. N. Agudelo. "Artificial wetland planted with Limonium Perezzi, for the treatment of wastewater from tanning", Revista Facultad de Ingeniería Universidad de Antioquia, no. 97, pp. 103-108, Oct-Dec 2020. [Online]. Available: https: //www.doi.org/10.17533/ udea.redin. 20200263

\section{ARTICLE INFO:}

Received: July 05, 2019 Accepted: February 10, 2020 Available online: February 10 , 2020

\section{KEYWORDS:}

Euhalophyte; retention time; organic load; salinity; Limonium Perezzi

Euhalófitas; tiempo de retención; carga orgánica; salinidad; Limonium Perezzi
ABSTRACT: The wastewater from leather tanning contains different types of pollutants depending on the internal process that is carried out, in particular, the riparian and tanning stages provide the greatest contaminant load within the process, in terms of organic matter, grease and oils, chlorides, chromium, sulfides among other substances. This study analyzed the efficiency of a biological treatment system, consisting of artificial wetlands of horizontal subsurface flow, in order to evaluate the removal of salinity and organic load present in the water produced during the process of soaking leathers. Two prototypes were tested, one planted with Limonium perezzi and the other unplanted as a control parameter, the wetlands were operated for 32 days. The results show that the planted wetland removes $49.2 \%$ of the initial chloride present $\left(44,414.8 \mathrm{mgCl}^{-} / \mathrm{L}\right)$ in the water and $86.2 \%$ of the total organic carbon $(755.9 \mathrm{mgC} / \mathrm{L})$. It was demonstrated that artificial wetlands are still a viable and efficient alternative in terms of organic load removal, on the other hand, the selected plant showed a very good performance in the treatment of wastewater because of its high tolerance to high concentrations of salt dissolved in the water, reaching perspiration of sodium chloride crystals through the leaves and stem.

RESUMEN: Las aguas residuales provenientes del curtido de cueros contienen distintos tipos de contaminantes dependiendo del proceso interno que se realice, en especial, las etapas de ribera y curtido aportan la mayor carga contaminante dentro del proceso, en términos de materia orgánica, grasa y aceites, cloruros, cromo, sulfuros entre otras sustancias. En este estudio se analizó la eficiencia de un sistema de tratamiento biológico, conformado por humedales artificiales de flujo horizontal subsuperficial, a fin de evaluar la remoción de salinidad y carga orgánica presentes en las aguas producidas durante el proceso de remojo de cueros. Dos prototipos se pusieron a prueba, uno plantado con Limonium perezzi y el otro sin plantar como parámetro de control, los humedales fueron operados por 32 días. Los resultados demuestran que el humedal plantado remueve el $49,2 \%$ del cloruro inicial presente $\left(44.414 .8 \mathrm{mgCl}^{-} / \mathrm{L}\right)$ en el agua y el $86,2 \%$ del carbono orgánico total $(755,9 \mathrm{mgC} / \mathrm{L})$. Se logró demostrar que los humedales artificiales siguen siendo una alternativa viable y eficiente en términos de remoción de carga orgánica, por otra parte, la planta seleccionada demostró un muy buen desempeño en el tratamiento del agua residual a causa a su alta tolerancia a elevadas concentraciones de sal disuelta en el agua, llegando a presentar transpiración de cristales de cloruros de sodio a través de las hojas y tallo.

\section{Introduction}

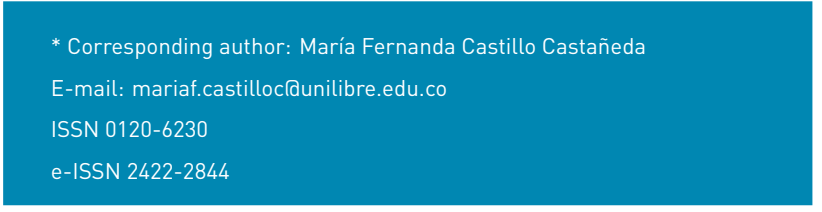

The tanning industry aims to transform animal skins into leather, for this purpose it is necessary to salt the skins in order to preserve them after the slaughter of the animal and thus being able to store the skins for long periods of time, so as to prevent the appearance 
of microorganisms that lead to their putrefaction. The preservation is carried out mainly by immersion in brine or addition of common salt [1]. Once the leather is received in the tanning company, it must be hydrated; this operation is known as soaking; in this operation a high volume of water is necessary, being the average consumption of 25 and $80 \mathrm{~m}^{3}$ per ton of raw processed material [2]. In the department of Cundinamarca, Colombia, the tanner sector focuses on the road corridor that joins the municipalities of Villapinzón and Chocontá. In this region, most of the tanneries carry out the processes in an artisanal way.

The wastewater generated in this type of industry contains high concentrations of salts, chromium, nutrients and organic matter, which makes the respective treatment difficult [2]. According to the above, these waters have high concentrations of (Biochemical Oxygen Demand $\mathrm{BOD}_{5}$, Chemical Oxygen Demand COD, Settleable Solids SS, Total Suspended Solids TSS, and Chloride $\mathrm{Cl}^{-}$), the average characteristics of the wastewater from tanneries are presented in Table 1.

Table 1 Summary of the pollutant load in the effluent from the soaking operation

\begin{tabular}{lcc}
\hline \multirow{2}{*}{ Pollutant load $(\mathbf{k g} / \mathbf{t}$ ) } & \multicolumn{2}{c}{ Technology } \\
\cline { 2 - 3 } & $\mathbf{C}$ & $\mathbf{A}$ \\
\hline $\mathrm{SS}$ & $11-17$ & $11-17$ \\
$\mathrm{DQO}$ & $22-33$ & $20-25$ \\
$\mathrm{DBO}_{5}$ & $7-11$ & $7-9$ \\
$\mathrm{NH}_{3-} \mathrm{N}$ & $0.1-0.2$ & $0.1-0.2$ \\
$\mathrm{TKN}^{-}$ & $1-2$ & $1-2$ \\
$\mathrm{Cl}^{-}$ & $85-113$ & $1-2$ \\
$\mathrm{SO}_{4}{ }^{2-}$ & $1-2$ & $1-2$ \\
\hline $\mathrm{C}:$ Conventional Technique \\
$\mathrm{A}:$ Advanced Technique \\
\hline \multicolumn{3}{c}{ Source: Adapted from [3] }
\end{tabular}

The presence of chlorides in very high concentrations makes it difficult to perform the biological treatment of wastewater; due to this, a subsurface flow wetland system was evaluated at a laboratory scale, in which a halophyte spice was planted for the treatment of Soaking sewage. Among the different techniques for the treatment of waters in tanneries, systems such as activated sludge, hybrid electrocoagulation and electrodialysis processes are used [4], wastewater treatment plants that include oxidation operations, and the use of synthetic materials in some processes, all of these in order to reduce the pollution emitted by the industry [5]. Artificial wetlands are used for the treatment of different types of water and are classified according to the type of flow and type of plant. These systems have been used to treat domestic waters for more than 30 years, wastewater from oil refinery industries, chemical factories, pulp and paper production, tannery and textiles. In Colombia, the use of artificial wetlands has been studied mainly for the treatment of domestic wastewaters, because conventional treatments are, in some cases, economically and environmentally unviable [6]. In the tanning industry, the use of wetlands has been studied with the main objective of removing organic matter using hybrid technologies lartificial wetland and microbial fuel cells to increase removal efficiency [7], in this case, it is necessary to determine the capacity of the plant to remove organic matter using water directly from soaking with extreme concentrations of chlorides and adaptable to the conditions of temperature and atmospheric pressure of the city of Bogotá.

Regarding halophytes plants, it should be noted that they have the advantage of growing in saline and arid zones. "Tolerance to salt and aridity is mainly due to the selective absorption of ions, osmoregulation, cell compartmentation and the synthesis of osmolytes" [8]. The plants commonly used in artificial wetlands are: Phragmites australis (emerging), Potamogeton crispus Linn (submerged) and Eichhornia crassipes Mart. (floating), which can be found around the world [9]. However, given the environmental conditions and availability of plants in the region, the wetland was planted with a halophyte species called Limonium Perezzi, known in the department of Cundinamarca as "estatice", which according to [10], is an euhalophyte, that is to say, they have the property of accumulating salt and secrete it through their buds, stems and leaves.

\section{Materials and methods}

The prototype of experimental artificial wetland was installed within the premises of the Universidad Libre of Colombia, Bosque Popular in Bogotá D.C, its laboratory was used for water quality analysis. The wetlands were installed in a place where they had ventilation and natural light, at a height of 2,630 meters above sea level and an average temperature of $14.55^{\circ} \mathrm{C}$ [11]. The wastewater used for the tests was supplied by a leather tanning company located in the municipality of Villapinzón, Cundinamarca, Colombia.

Two laboratory-scale units were built, one planted with Limonium Perezzi and the other used as a control sample. The structure of the prototypes presented a volume of $0.0225 \mathrm{~m}^{3}$, the measures of the prototype were $0.295 \mathrm{~m}$ wide, $0.41 \mathrm{~m}$ long, $0.30 \mathrm{~m}$ high as illustrated in the Figure 1 , the substrate layers, the residual water and halophytic plants were introduced into the container. The filling substrate was formed with $0.22 \mathrm{~m}$ gravel, diameter less than $0.0254 \mathrm{~m}$, river sand and soil to provide support to the plants, sown plants had heights of $0.08 \mathrm{~m}, 0.06 \mathrm{~m}$ and 0.08 $\mathrm{m}$ (the porosity of the bed was 0.35 ). To distribute the water within each prototype, perforated screens were installed at 
the entrance and exit of each wetland. The useful surface area of each wetland was $0.326 \mathrm{~m}^{2}$, the average height of the water in the wetland was $0.185 \mathrm{~m}$. The residual water was fed by means of peristaltic pumps, which ensured a constant flow of $2.38 \times 10^{-7} \mathrm{~m}^{3} / \mathrm{s}$, each wetland was operated for 32 days, according to the volume and the porosity of the tank, the water retention time within each wetland was 4 days, so water sampling was carried out at the exit of the wetland once the retention time had elapsed.

Halophyte plants of the genus Limonium, Limonium Perezzi species are found in the region and can survive between 1,000 and 2,620 meters above sea level, therefore, they can adapt to coastal areas and cold climates. They were planted by hand in such a way that the fertilizer covered the roots in their entirety [12].

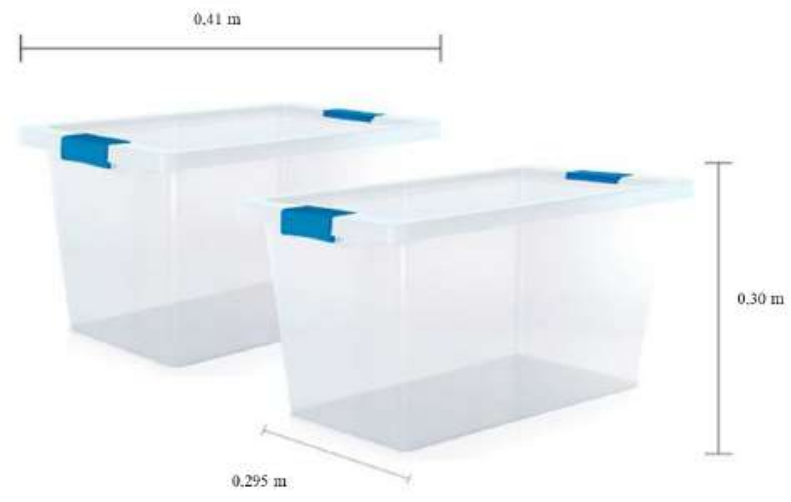

Figure 1 Dimensions of artificial wetland prototypes

\subsection{Water quality analysis}

The residual water from the soaking process was supplied by a leather tanning company located in the municipality of Villapinzón. The characterization of the water was carried out at the entrance and exit of the wetland, the parameters analyzed were $\mathrm{pH}$, conductivity, turbidity, temperature, chloride concentration and total organic carbon; the analysis of each parameter was performed based on the standard methods for drinking water and residual analysis [13], the TOC analysis was done in an equipment for the determination of Total Organic Carbon Analyzer (Shimadzu). In order to analyze or evaluate the retention of salinity in the wetland, determine conductivity, dissolved solids and chlorides in the water using the methods described in the book, standard methods for analysis of drinking water and residual, [13]. It is important to mention that the salt tolerance of the plant was verified, by observing the physical and biological characteristics of the plant in order to evaluate its ability to adapt to the environment and possible degradation of plant material, for this, visual inspection and photographic record of the coloring of the leaves was carried out.

\section{Result and discussion}

Table 2 shows the results obtained in the characterization of the wastewater fed to each of the wetlands.

Table 2 Characterization of the waters of the soaking operation before entering the wetland

\begin{tabular}{lcc}
\hline \multirow{2}{*}{ Parameter } & Unity & Value \\
\cline { 3 - 3 } & & HP \\
\hline $\mathrm{pH}$ & $\mathrm{pH}$ units & 6.3 \\
Temperature & ${ }^{\circ} \mathrm{C}$ & 18.5 \\
Turbidity & $\mathrm{UNT}$ & 156 \\
Conductivity & $\mathrm{mS} / \mathrm{cm}$ & 60.3 \\
Dissolved Solids & $\mathrm{g} / \mathrm{L}$ & 26.2 \\
Organic Material & Absorbance at 254 nm & 3.324 \\
Chlorides & $\mathrm{mg} / \mathrm{L}$ & $44,414.2$ \\
TOC & $\mathrm{mg} / \mathrm{L} \mathrm{C}$ & 755.9 \\
\hline
\end{tabular}

The $\mathrm{pH}$ of the water sample is slightly acid, this parameter is important considering that it affects the conditions of removal of pollutants from saline waters [9]. In addition, the Limonium genus requires, for an adequate development of the crop, to maintain slightly acid soils, with a pH of 6.2 to 6.5 [14]. It is observed that the concentration of chlorides is considerably high compared to the project developed by Calheiros, Rangel, \& Castro in Portugal, in which they tested an artificial wetland of subsurface horizontal flow for the treatment of wastewater with high salinity (2.2-6.6 $\left.\mathrm{g} \mathrm{Cl}^{-} / \mathrm{l}\right)$ from a tanning industry [2]; based on this, the salt tolerance capacity of the plant is evidenced or projected. Likewise, the electrical conductivity in an artificial vertical wetland system planted with halophytes to treat domestic wastewater is lower than that presented in this case $(2.23 \mathrm{mS} / \mathrm{cm})[2]$. So, in the case analyzed, the conditions to which the plants were submitted turned out to be significantly more demanding than those of the previous study.

\subsection{Efficiencies of removal of the wetland at scale}

The results of characterization of the quality parameters of the residual water passing through the wetland after the respective retention time ( 4 days), are presented in Table 3 , in total eight samples were taken so that the total time of wetland operation was 32 days, wastewater effluents from the treatment system were collected and fed back to the wetland.

When comparing the results obtained for the planted and unplanted wetland, it is observed that the turbidity of the water diminishes due to the filtration in the 
Table 3 Characterization of the water in the samples at the exit of the wetland

\begin{tabular}{llllll}
\hline Time (days) & Chlorides $(\mathbf{m g} / \mathbf{L})$ & \multicolumn{7}{c}{ TOC (mg/L) } & Conductivity $(\mathbf{m S} / \mathbf{c m})$ & Turbidity (UNT) & $\mathbf{p H}$ \\
\hline \multicolumn{7}{c}{ Planted Wetland } \\
\hline 0 & 455.87 & 60.3 & 133 & 6.2 \\
4 & $36,149.18$ & 395.95 & 41.2 & 49.57 & 6.4 \\
8 & $33,132.89$ & 336.83 & 38.5 & 41.95 & 6.6 \\
12 & $30,794.02$ & 230.93 & 38.2 & 36.05 & 6.9 \\
16 & $29,008.86$ & 188.88 & 37.4 & 35.06 & 7.0 \\
20 & $28,116.28$ & 175.33 & 36.9 & 34.56 & 6.8 \\
24 & $25,623.70$ & 144.65 & 33.4 & 33.3 & 6.7 \\
28 & $24,331.12$ & 110.98 & 33.1 & 32.58 & 7.2 \\
32 & $22,545.96$ & 104.13 & 32.7 & 10.28 & 7.0 \\
\hline \multicolumn{7}{c}{ Blank Wetland } \\
\hline 0 & $45,967.89$ & 755.05 & 58.3 & \\
32 & $41,326.47$ & 523.60 & 51.2 & 156 \\
\hline
\end{tabular}

gravel and sand layers in each wetland; however, in the planted wetland, the percentage of removal is greater consistent with the role played by vegetation, which through biodegradation (aerobic and anaerobic) allows the removal of organic matter and turn the turbidity present [15].

Some operational parameters were based on the Equation 1 and Equation 2, which are part of the scaling process of artificial wetlands.

\section{Transverse flow rate}

$$
\begin{aligned}
& V s=\frac{Q}{\varphi * b * h}= \\
& \frac{2.38 \times 10^{-7} \mathrm{~m}^{3} / \mathrm{s}}{0.35 \mathrm{~m} * 0.295 \mathrm{~m} * 0.22 \mathrm{~m}}= \\
& \quad 1.05 \times 10^{-5} \mathrm{~m} / \mathrm{s}
\end{aligned}
$$

In the above equation, $V s$ is the transverse flow velocity in $\mathrm{m} / \mathrm{s}, Q$ is the flow in $\mathrm{m}^{3} / \mathrm{s}, b$ is the width in meters $(\mathrm{m})$, $h$ the height of the bed in meters $(\mathrm{m})$ and $\emptyset$ the porosity of the filter bed.

\section{Hydraulic Load}

$$
\begin{aligned}
& q=\frac{Q}{b * h}= \\
& \frac{0.0206 \mathrm{~m}^{3} / \text { day }}{0.295 \mathrm{~m} * 0.22 \mathrm{~m}}= \\
& 0.317 \mathrm{~m} / \text { day }
\end{aligned}
$$

In the previous equation, $q$ is the hydraulic load in $\mathrm{m} /$ day, $Q$ is the flow in $\mathrm{m}^{3} / \mathrm{s}, b$ is the width in meters $(\mathrm{m}), h$ the height of the bed in meters $(\mathrm{m})$.

\section{Planting density}

Planting density or crop density is defined as the number of plants per unit of land area, this parameter allows identifying the effects in the cultivation of a plant, due to the competition of this with other plants of the same or another species. The length of the growth period, the characteristics of the plant and the available resources are some factors to consider when determining the density of plantation [16].

According to [16], an optimum and economic plantation density for coffee plantations is estimated from different equations to represent planting density, which allow establishing: Optimal biological: 11,033 plants/ha and Optimal economic: 9,404-9,852 plants/ha. However, it is recommended that the Limonium be planted on $100 \mathrm{~cm}$ sidewalks, with $50 \mathrm{~cm}$ corridors. A density of 5 plants per square meter is considered optimal for cultivation [17]. The planting density of the wetlands used in the project is determined as Equation 3, below:

$$
\begin{gathered}
\text { Planting Density }=\frac{\text { Number of plants }}{\text { Superficial area }}= \\
\frac{2}{0.326 \mathrm{~m}^{2}}=
\end{gathered}
$$

$$
6.12 \text { plants } / \mathrm{m}^{2}
$$

The selection of the halophyte plant considers its capacity to grow in a reduced environment and the capacity to accumulate sufficient ions in its tissues in order to reduce the salinity and organic matter of the wastewater. In the exposed results, it is observed that the Limonium Perezzi, has the capacity to absorb the chloride salts that are present in the residual water of soaking, salts that later secret through its leaves and stems, the salt was collected and weighed resulting in $1,096 \mathrm{~g}$ sodium chloride, as shown in Figure 2. 


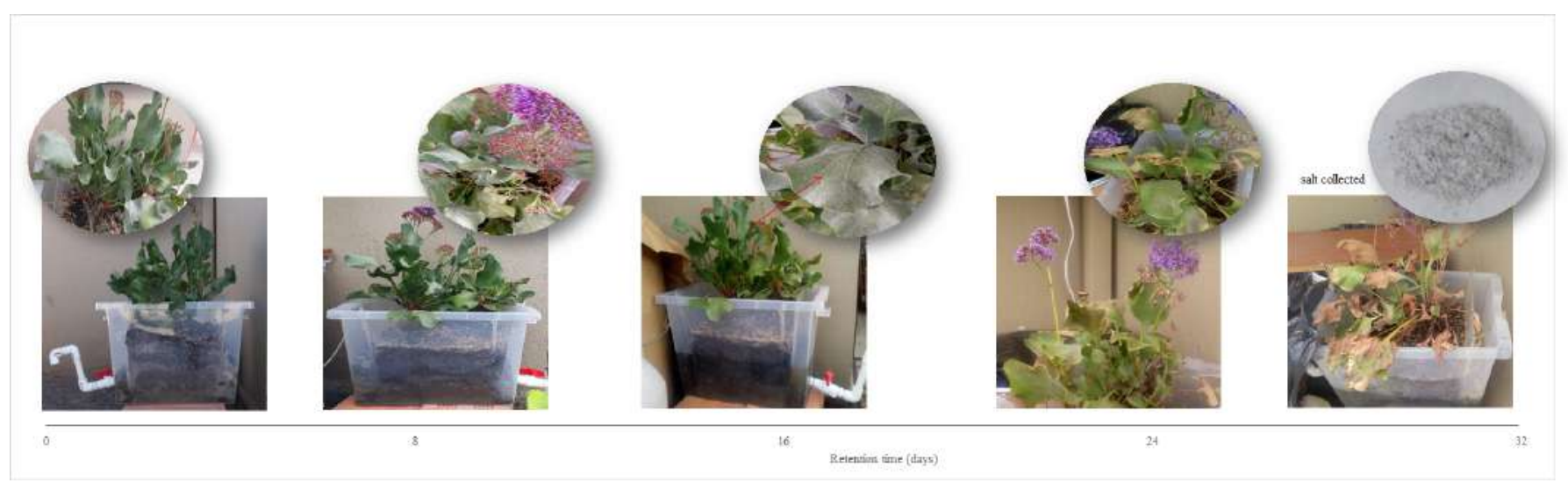

Figure 2 Photographic record of the plants during the start-up of the wetland

\subsection{Development of plants}

During the development of the process, the growth and development of the plants was monitored, the coloring of the leaves was considered, for this the photographic record of the plants is taken during days $0,8,16,24$ and 32.

Salinity is a factor that limits the productivity of plants due to its high sensitivity to this condition, in saline environments, $\mathrm{Na}^{+1}$ and $\mathrm{Cl}^{-1}$ are the dominant ions [18]. Although $\mathrm{Cl}$ is an essential element for the growth of plants, it can cause toxicity in cases where the concentration in the plant tissue is excessive. High concentrations of $\mathrm{Cl}^{-}$produce burns on the leaves, decrease photosynthesis and inhibit the absorption of nitrates [19]. Additionally, salinity causes effects in the concentration of pigments mainly by the destruction of chlorograplasts and increase in the activity of the chlorophyllase enzyme that affects the synthesis of chlorophyll, therefore, plants that are found in saline environments can present chlorosis and abscission of adult leaves [18].

In the tanning industry, biological treatments have been implemented for the removal of contaminants due to the chemicals used during the different operations, in the case of [20], halophilic bacteria are used to treat wastewaters from tanneries and determined that salinity affects more the removal of COD, total nitrogen and suspended solids than retention time, they find that for a retention time of 5 days they manage to remove they can remove up to $95 \%$ of organic load, but did not evaluate the removal of chlorides. Additionally, Calheiros, Rangel, \& Castro tested a subsurface horizontal flow artificial wetland for the treatment of wastewater with high salinity (2.2-6.6 $\mathrm{g} \mathrm{Cl}^{-} \mathrm{L}^{-1}$ ) from a leather company in Portugal, these were planted with Arundo donax and Sarcocornia fructicosa, both wetlands performed equally for COD $165 \%$ removal), $\mathrm{BOD}_{5}(73 \%)$, TSS (65\%), $\mathrm{NH}_{4}-\mathrm{N}(73 \%)$ and TKN
(75\%) while removal of TP was slightly higher in Arundo wetland $(83 \%)$ as compared to Sarcocornia wetland $(79 \%)$ [2]. Finally, in this study, they evaluated the ability of Chlorella vulgaris to remove organic matter, nitrogen and phosphorus by finding removals between $99 \%$ and $65 \%$ removal of these parameters [21].

\section{Conclusions}

The Limonium Perezzi plant used in the biological treatment of wastewater from the soaking process in the tanning industry, has faculties to survive in saline environments and to resist water with a concentration of chlorides greater than $20,000 \mathrm{mg} / \mathrm{L}$. The planted wetland reached a percentage of chloride removal of $47.12 \%$.

The horizontal flow artificial wetlands can be an efficient alternative to remove organic matter and turbidity of water, this thanks to the filtration process that occurs in the different layers of the substrate and the need for production of the plant, the effectiveness of removal of organic matter and turbidity that was reached in the wetland is $86.22 \%$ and $92.27 \%$, respectively.

At the end of 32 days of operation the plants die, due to the high concentration of chlorides, a fact that can be modified by increasing the population density of the plants to distribute the salt load.

The plant removes or expels sodium chloride crystals through the leaves and stem, therefore it does not completely bioaccumulate the salt, retains it and expels it, which makes its use attractive for desalination processes, which can be considered in the possibility of recovering the salt for later use in other activities. 


\section{Declaration of competing interest}

None declared under financial, professional and personal competing interests.

\section{Acknowledgements}

The authors express their thanks to Mr. Leovicedo Fernández and Mr. Helmun Fernández, owners of the Leofer tannery, for allowing the sampling of residual water and the Universidad Libre for providing space for the installation of the prototype, equipment and laboratory elements.

\section{References}

[1] Secretaría Distrital de Ambiente - SDA. Guía de producción más limpia para el sector curtiembres de Bogotá. Enfoque en vertimientos y residuos. Secretaría Distrital de Ambiente - SDA. Bogotá, Col. [Online]. Available: https://bit.ly/2RSSF6l

[2] J. Vymazal. (2014, December) Constructed wetlands for treatment of industrial wastewaters: A review. [Online]. Available: https: //doi.org/10.1016/j.ecoleng.2014.09.034

[3] O. Tunay, I. Kabdasli, I. Arslan, and T. Olmez, Chemical Oxidation Applications for Industrial Wastewaters. London, NY: IWA Publishing, 2010.

[4] A. Deghles and U. Kurt. (2016, June) Treatment of tannery wastewater by a hybrid electrocoagulation/electrodialysis process. [Online]. Available: https://doi.org/10.1016/j.cep.2016.02.009

[5] L. Artuz, M. Martínez, and C. Morales, "Las industrias curtiembres y su incidencia en la contaminación del río Bogotá," Isocuanta, vol. 1, no. 1, pp. 43-53, 2011

[6] C. A. Díaz, "Tratamiento de agua residual a través de humedales," in $\checkmark$ Congreso Internacional de Ingeniería Civil, Universidad Santo Tomás Seccional Tunja, Tunja, Colombia, 2014, pp. 1-8.

[7] P. Srivastava, R. Abbassi, V. Garaniya, T. Lewis, and A. K. Yadav, "Performance of pilot-scale horizontal subsurface flow constructed wetland coupled with a microbial fuel cell for treating wastewater," J. Water Process Eng., vol. 33, February 2020. [Online]. Available: https://doi.org/10.1016/j.jwpe.2019.100994
[8] A. Hotterer, G. Hertenberger, and J. Polania, "Sobre la ecofisiologia de plantas halofitas y deserticas," Acta Biológica Colombiana, vol. 2, no. 6, pp. 9-21, 1990.

[9] Y. Liang and et al, "Constructed wetlands for saline wastewater treatment: A review," Ecol. Eng., vol. 98, January 2017. [Online]. Available: https://doi.org/10.1016/j.ecoleng.2016.11.005

[10] Y. Waisel, "Classification," in Biology of halophytes, Y. Waisel, Ed. Academic Press, 1972, pp. 40-45.

[11] G. Esguerra, “El problema de la hipertrofia cardiaca en los habitantes de las alturas," Revista de la Universidad Nacional, no. 10, pp. 273-285, 1947.

[12] R. Bernal, S. R. Grandstein, and M. Celis. (2014) Catálogo de plantas y líquenes de Colombia. [UNAL]. Accessed. [Online]. Available: http://catalogoplantasdecolombia.unal.edu.co/es/

[13] Standard methods for the examination of water and wastewater, $22^{\text {nd }}$ edition, APHA, 2012

[14] S. Santana, “Aspectos técnicos de producción y comercialización de la flor de complemento Limonium (Sinatum Y Latifolium spp) en el estado de México," M.S. thesis, Universidad Autónoma Agraria Antonio Narro, Saltillo, México, 2009.

[15] M. S. Fountoulakis, G. Sabathianakis, I. Kritsotakis, E. M. Kabourakis, and T. Manios, "Halophytes as vertical-flow constructed wetland vegetation for domestic wastewater treatment," Sci. Total Environ., vol. 583, April 1 2017. [Online]. Available: https://doi.org/10.1016/j.scitotenv.2017.01.090

[16] J. Arcila, "Densidad de siembra y productividad de los cafetales," in Sistemas de producción de café en Colombia, J. Arcila, F. Farfán, A. Moreno, L. F. Salazar, and E. Hincapié, Eds. Chinchiná, Col: Cenicafé, 2007, pp. 131-146.

[17] C. Lijalad, “Limonium,” Horticultura, no. 84, pp. 29-35, 1993.

[18] N. Villavicencio, C. López, M. Basurto, and R. Pérez, “Efectos por salinidad en el desarrollo vegetativo," Tecnociencia Chihuahua, vol. 5, no. 3, pp. 156-161, 2011.

[19] M. Villa, E. A. Catalán, M. A. Inzunza, and A. L. Ulery, “Absorción y traslocación de sodio y cloro en plantas de chile fertilizadas con nitrógeno y crecidas con estrés salino," Revista Fitotecnia Mexicana, vol. 29, no. 1, pp. 79-88, ene-mar 2006.

[20] O. Lefebvre, N. Vasudevan, M. Torrijos, K. Thanasekaran, and R. Moletta, “Halophilic biological treatment of tannery soak liquor in a sequencing batch reactor," Water Res., vol. 39, no. 8, April 2005. [Online]. Available: https://doi.org/10.1016/j.watres.2004.12.038

[21] D. Saranya and S. Shanthakumar, “Green microalgae for combined sewage and tannery effluent treatment: Performance and lipid accumulation potential," J. Environ. Manage., vol. 241, July 12019. [Online]. Available: https://doi.org/10.1016/j.jenvman.2019.04.031 